\title{
Proof of Concept for the Dual Membrane Cell
}

\section{Fabrication and Electrochemical Testing of First Prototypes}

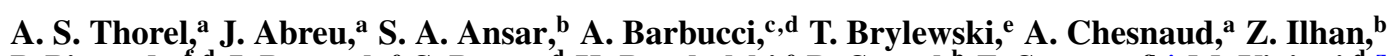 \\ P. Piccardo, ${ }^{\mathrm{f}}, \mathrm{d}$ J. Prazuch, ${ }^{\mathrm{e}}$ S. Presto, ${ }^{\mathrm{d}}$ K. Przybylski, ${ }^{\mathrm{e}}$ D. Soysal, ${ }^{\mathrm{b}}$ Z. Stoynov, ${ }^{\mathrm{g}, *}$ M. Viviani, ${ }^{\mathrm{d}, \mathrm{z}}$ \\ and D. Vladikova ${ }^{\mathrm{g}, *}$
}

\author{
${ }^{a}$ Mines-ParisTech, Centre des Matériaux, UMR CNRS 7633, Evry Cedex 91003, France \\ ${ }^{b}$ German Aerospace Center (DLR-ITT), Stuttgart D-70569, Germany \\ ${ }^{c}$ Department of Chemical and Process Engineering (DICHeP), University of Genova, Genova 16129, Italy \\ ${ }^{d}$ Institute for Energetics and Interphases (IENI-CNR), National Research Council, Genova 16149, Italy \\ ${ }^{e}$ Department of Solid State Chemistry, AGH University of Science \& Technology, PL-30059 Krakow, Poland \\ ${ }^{f}$ Department of Chemistry and Industrial Chemistry (DCCI), University of Genova, Genova 16146, Italy \\ ${ }^{g}$ Institute of Electrochemistry and Energy Systems, Sofia 1113, Bulgaria
}

\begin{abstract}
The Dual Membrane Cell (DM-Cell) is an innovative concept for solid state fuel cells operating in the temperature range $600-700^{\circ} \mathrm{C}$. It is based on a junction between the cathode/electrolyte part of a Solid Oxide Fuel Cell (SOFC) and the anode/electrolyte part of a protonic SOFC (PCFC) via a mixed $\mathrm{H}^{+}$and $\mathrm{O}^{2-}$ conducting porous ceramic membrane, named Dual Membrane (DM). This Dual Membrane is the key feature of the DM-Cell architecture and constitutes a third independent gas compartment for water formation and evacuation. This innovation is expected to reduce the drawbacks associated to the presence of water at one or the other electrodes taking place in conventional SOFC and PCFC. The proof of the DM-Cell concept was obtained by several dedicated experiments, i.e. through the electrical characterization of complete cells in a three-compartments rig, specifically designed to detect water vapor formation in the DM compartment. The paper reports the proof of the concept of the DM-Cell through a set of electrochemical results performed on thick model cells. The applicability of a potentially industrial shaping process to this new design is demonstrated on plasma sprayed metal supported complete dual membrane cell.

(C) 2013 The Electrochemical Society. [DOI: 10.1149/2.051304jes] All rights reserved.
\end{abstract}

Manuscript submitted November 26, 2012; revised manuscript received January 28, 2013. Published February 7, 2013. This was

Paper 1281 presented at the Vienna, Austria, Meeting of the Society, October 4-9, 2009.

Conventional solid oxide fuel cells (SOFC) and proton conducting solid oxide fuel cells (PCFC) are promising high-temperature fuel cell systems, though at different stages of development. SOFCs are more mature, and prototypes do exist with geometries derived from two main different designs, tubular and planar. In either case, the SOFC system is mainly operated in the range $800-1000^{\circ} \mathrm{C}$ and state of the art cells are based on Yttria-Stabilized Zirconia (YSZ) for the electrolyte, Ni-YSZ cermet for the hydrogen electrode (anode) and lanthanum-strontium-manganese oxide (LSM) for the air electrode (cathode). Recent developments have brought about a decrease in SOFC operating temperatures closer to $700^{\circ} \mathrm{C}$, thanks to the anodeor metal-supported design with thin electrolyte layers, and through new materials development, mainly Y or Gd-substituted cerium oxide (YDC or GDC respectively) for electrolyte and lanthanum-strontiumcobalt-iron-oxide (LSCF) for cathode. ${ }^{1}$

The advent of a different mechanism for conduction in PCFCs has given rise to a new impetus in the fuel cell field. These systems, whose electrolyte is based on barium cerate or zirconate perovskitelike structures, offer higher efficiency than conventional SOFC thanks to the lack of fuel dilution in the anode and operative temperature around $600^{\circ} \mathrm{C}$. Although performances of PCFC are mainly limited by the activity and stability of cathode materials, recent development of nickelates and cobaltites ${ }^{2,3}$ allowed very promising results. ${ }^{4}$

Though potentially very attractive in the long term, SOFC stacks based on YSZ present limitations in the electrical efficiency which rarely exceeds 50-60\%. ${ }^{5}$ This, in addition to the important costs of development and manufacture and to non negligible performance degradation $(\approx 0.5 \% / 1000 \mathrm{~h})$, significantly slows down their marketing.

Even if a few SOFC prototypes have already exhibited some 10,000 hours of stable operation, ${ }^{6}$ both SOFC and PCFC technologies still suffer from thermodynamic, kinetic and technological drawbacks, which are directly linked to the unavoidable occurrence of water at the anode in SOFC and at the cathode in PCFC.

The catalytic activity of the electrodes and mass transfer at high current density are also affected by water vapor as it decreases on the one hand surface coverage of sites active for $\mathrm{H}_{2}$-oxidation (or

*Electrochemical Society Active Member.

${ }^{\mathrm{z} E}$-mail: m.viviani@ge.ieni.cnr.it
$\mathrm{O}_{2}$-reduction) and as it impedes on the other hand the mobility of reactants, therefore rising the polarization resistance of electrodes. ${ }^{7}$ In addition, water vapor can deeply affect durability of cells and stacks, through anode inactivation due to $\mathrm{Ni}$ particles oxidation ${ }^{7}$ and interconnects corrosion that can be several orders of magnitude faster than under dry conditions. ${ }^{8}$

The DM-Cell architecture, patented in $2005^{9}$ and extensively studied by a European consortium from 2008 to $2012^{10}$ was firstly reported in the literature in $2009,,^{11}$ although the electrochemical properties of a junction between PCFC and SOFC electrolytes had been originally explored by Bonanos in $1993,{ }^{12}$ who suggested it could be used as a water sensor, and by Shimura et al. in $1997,{ }^{13}$ who used it to demonstrate the presence of proton conduction in $\mathrm{SrZrO}_{2}$ at $600^{\circ} \mathrm{C}$. The DM-Cell architecture strongly reduces the above listed disadvantages, still keeping the benefits of SOFC and PCFC while allowing for a simpler management of pressurization of electrode compartments, which is highly recommended for both increasing efficiency, i.e. the cell voltage (see Eq. 1) and the activity of electrodes, and coupling with gas turbines. ${ }^{14}$

This paper is focused on the experimental proof of the DM-Cell concept performed on thick model cells. The supporting theoretical background is the subject of a companion paper. ${ }^{15}$ The first step of the DM design toward industrialization is investigated via the fabrication of a thin metal supported plasma sprayed cell.

\section{The DM-Cell Concept}

The basic ideas behind the concept.- The concept joins a PCFC anode/electrolyte part (anode compartment) and a SOFC electrolyte/cathode part (cathode compartment) via a mixed $\mathrm{H}^{+}$and $\mathrm{O}^{2-}$ conducting porous ceramic membrane, constituted by a composite made of mixed PCFC and SOFC electrolyte materials (Figure 1) and named Dual Membrane (DM).

Protons created at the anode and oxygen ions created at the cathode drift across their respective electrolytes toward the DM, where they come in contact at triple phase segments to form water, which is evacuated through the porous DM itself. Therefore, in this concept hydrogen, oxygen and water are located in three independent volumes, 


\section{IDEAL Cell}

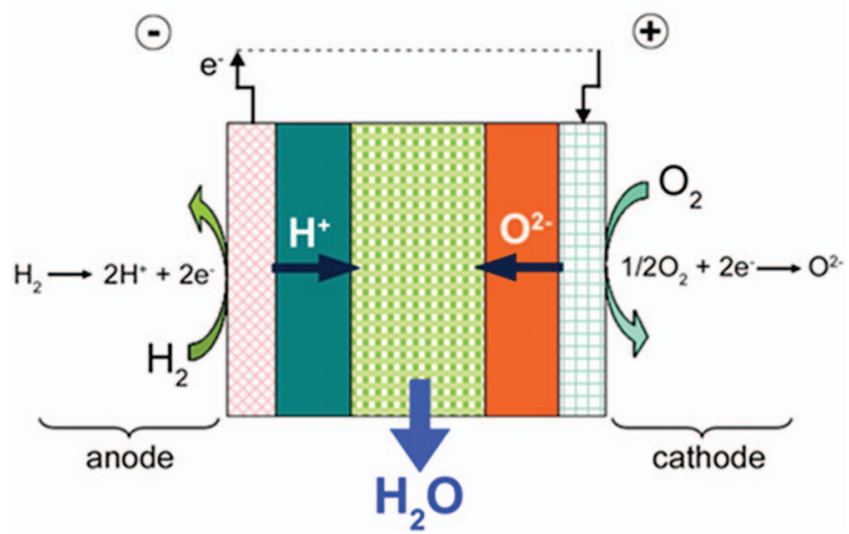

Figure 1. Schematic representation of the DM-Cell concept: water is formed in a third compartment.

which allows for the avoidance of all the detrimental consequences discussed above.

The innovative concept has the potential to considerably enhance the overall efficiency and durability of SOFC systems thanks to finetuning of the catalytic properties of electrodes, easier pressurization of both electrode compartments without the need of constant purging produced water, production of pure water for steam reforming and elimination of corrosion mechanisms in interconnects related to water, such as the surface modification of Chromia protective layer and promotion of $\mathrm{Fe}$ migration ${ }^{16}$

For a hydrogen fueled cell, the open circuit voltage $(E)$ depends on the partial pressure of reacting species, according to the reaction $\mathrm{H}_{2}+\frac{1}{2} \mathrm{O}_{2} \rightarrow \mathrm{H}_{2} \mathrm{O}$, as expressed by the Nernst equation:

$$
E=E^{0}+\frac{R T}{2 F} \ln \left(\frac{\alpha \beta^{\frac{1}{2}}}{\delta}\right)+\frac{R T}{4 F} \ln \left(\frac{P}{P_{0}}\right)
$$

where $\alpha \mathrm{P}, \beta \mathrm{P}$ and $\delta \mathrm{P}$ are the partial pressures of $\mathrm{H}_{2}, \mathrm{O}_{2}$ and $\mathrm{H}_{2} \mathrm{O}$ gases respectively, $\alpha, \beta$ and $\delta$ are the molar ratios of $\mathrm{H}_{2}, \mathrm{O}_{2}$ and $\mathrm{H}_{2} \mathrm{O}, P$ is the total pressure, assumed equal at both sides of the cell, and $P_{0}$ is the reference pressure (commonly $1 \mathrm{~atm}$.). ${ }^{17}$ Thus, water formation lowers either $\alpha$ (SOFC) or $\beta$ (PCFC), reducing the reversible cell's voltage. This effect is particularly marked under high fuel utilization or, equivalently, at high current density. Equations 2-4 express the molar ratios of reactants and product for each type of fuel cell, where $U$ is the ratio of utilized to fed moles of fuel (hydrogen):

$$
\begin{array}{ll}
\text { SOFC : } & \alpha=1-U ; \quad \beta=1 ; \quad \delta=U \\
\text { PCFC : } & \alpha=1 ; \quad \beta=\frac{1-U / 2}{1+U / 2} ; \quad \delta=\frac{U}{(1+U / 2)}
\end{array}
$$

$$
\text { DM-Cell : } \quad \alpha=1 ; \quad \beta=1 ; \quad \delta=X ; \quad 0<X \leq 1
$$

In the case of DM-cell, the water vapor molar ratio $X$ can be changed at ease by adding an inert carrier gas in the DM compartment. Replacing such expressions in Eq. 1, a comparison of the reversible voltage as a function of $U$ for the three architectures can be done: Figure 2 shows the superior efficiency of the DM-cell, particularly at high levels of fuel utilization and for higher dilution of water vapor in the DM compartment, calculated under constant flow rate of carrier gas.

Proof of concept (PoC) criteria.- A set of four operational criteria was elaborated in order to identify the DM-Cell as a fuel cell and especially to demonstrate the 3-compartments operational mode explained above. In particular:

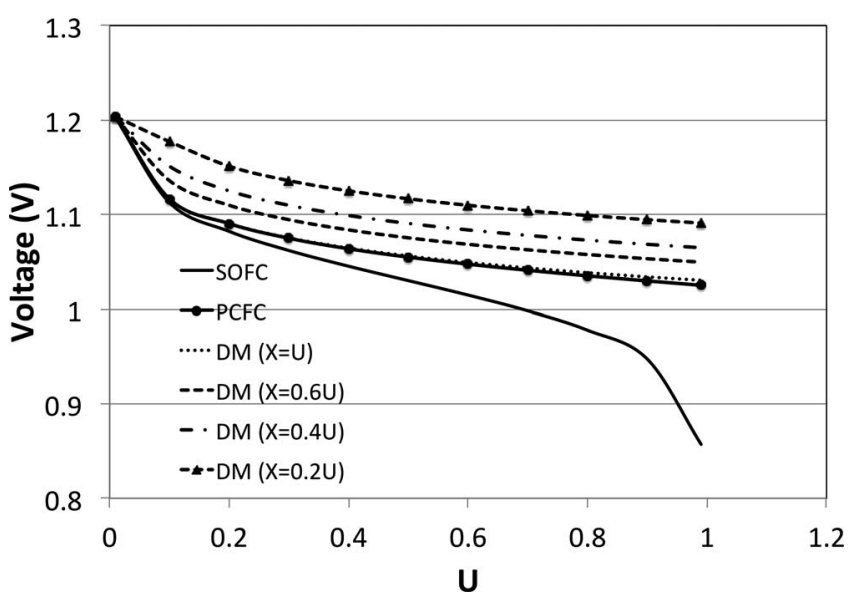

Figure 2. Cell voltage dependence on the utilization factor $\mathrm{U}$ for SOFC, PCFC and the DM-Cell at $600^{\circ} \mathrm{C}$ and for $\mathrm{H}_{2} / \mathrm{O}_{2}$ feeding. The curves for the DM-cell are calculated for different dilution of water vapor in the DM compartment obtained with a constant flow rate of carrier gas..

(i) establishment of a stable OCV on hydrogen and air feeding,

(ii) measurement of a stable polarization curve (V/I),

(iii) detection of humidity changes in the DM compartment on cell polarization/depolarization,

(iv) identification of a specific impedance fingerprint for the appearance of water.

The two first criteria are relevant to standard electrochemical behavior of all types of fuel cell, while the two last deal with special features that are specific to the DM-Cell. As a small amount of water vapor was intentionally introduced at the anode together with $\mathrm{H}_{2}$ gas for proper hydration of the protonic electrolyte, and taking into account some leakage, the proof of point (iii) required considering deviation of the humidity from a steady baseline. Point (iv), verified experimentally, was the main subject of a recent paper $^{18}$ and will not be discussed in the following.

\section{Experimental}

Materials. - Cells for the proof of the concept (PoC) were based on existing materials, physically and chemically compatible ${ }^{19,20}$ (compatible thermal expansion coefficients and negligible reactivity), and showing significant conductivity already at $600^{\circ} \mathrm{C}$.

The following sequence of materials was selected:

- $\mathrm{BaCe}_{0.85} \mathrm{Y}_{0.15} \mathrm{O}_{2.925}$ (BCY15) $+\mathrm{Ni}$ for the anode

- $\mathrm{BaCe}_{0.85} \mathrm{Y}_{0.15} \mathrm{O}_{2.925}$ for the hydrogen electrolyte

- $\mathrm{BaCe}_{0.85} \mathrm{Y}_{0.15} \mathrm{O}_{2.925}+\mathrm{Ce}_{0.85} \mathrm{Y}_{0.15} \mathrm{O}_{1.925}$ (YDC15) for the DM

- $\mathrm{Ce}_{0.85} \mathrm{Y}_{0.15} \mathrm{O}_{1.925}$ for the oxygen electrolyte

- $\mathrm{La}_{0.60} \mathrm{Sr}_{0.40} \mathrm{Co}_{0.20} \mathrm{Fe}_{0.80} \mathrm{O}_{3-\delta}$ (LSCF48) for the cathode

YDC15 was preferred to the more standard Gd-doped Ceria in order to minimize the yttrium chemical gradient across the cell and hence to increase the stability under operation. The amount of acceptor dopant selected for BCY15 corresponds to the maximum conductivity at $600^{\circ} \mathrm{C}^{21}$

Fine powders $\left(\mathrm{d}_{50}=0.2 \mu \mathrm{m}\right)$ of $\mathrm{Ce}_{0.85} \mathrm{Y}_{0.15} \mathrm{O}_{1.925}$ (YDC15) and $\mathrm{BaCe}_{0.85} \mathrm{Y}_{0.15} \mathrm{O}_{2.925}$ (BCY15) were prepared by the oxalate precipitation route while coarser $\left(\mathrm{d}_{50}=1.3 \mu \mathrm{m}\right) \mathrm{La}_{0.60} \mathrm{Sr}_{0.40} \mathrm{Co}_{0.20} \mathrm{Fe}_{0.80} \mathrm{O}_{3-\delta}$ (LSCF48) powders were prepared by a self-combustion process. Before any processing, powders were ball milled overnight and sieved. Cathode material powders for thermal spray deposition were specifically granulated by spray drying in order to ensure flowability of solid feedstock. Average size of aggregates was $20 \mu \mathrm{m}$.

Fabrication of PoC cells. - The planar structure of a DM-Cell consists of five different layers, porous or dense, each having proper 
composition and microstructure depending on the specific role it has to play. Electrolytes must be gastight and ideally possess unit or zero transport number for the relevant ionic species, i.e. $\mathrm{H}^{+}$or $\mathrm{O}^{2-}$. The $\mathrm{DM}$, which is the key-point for the cell operation, should have high conductivity for both ionic species and high gas permeability for water vapor removal. A careful control of percolation and tortuosity of solid phases and porosity in the DM microstructure is therefore required, as also indicated by modeling results. ${ }^{15}$

Multilayered ceramic proof of concept (PoC) samples (10-20 mm in diameter), consisting in a DM sandwiched between the two types of electrolytes $\left(\mathrm{H}^{+}\right.$and $\mathrm{O}^{2-}$ conducting ions respectively) were fabricated either by Spark Plasma Sintering (SPS), Hot Pressing (HP) or by Cold Pressing (CP) and Tape casting (TC) in order to verify the proof of concept criteria. For the electrochemical characterization of all the PoC cells mentioned above, circular Pt electrodes (0.12$0.79 \mathrm{~cm}^{2}$ ) instead of ceramic electrodes were deposited on both sides of the PoC samples by brushing and curing at $1000^{\circ} \mathrm{C}$ a Pt-ink (Metalor) to avoid variability from one shaping process to the other and to limit the non essential shaping difficulties at this proof of concept step.

Thick (about $3 \mathrm{~mm}$ ) samples, made of BCY15 / BCY15 + YDC15 + graphite / YDC15 were prepared by SPS without any addition of sintering aid to the starting powders. The samples were heated up at $200^{\circ} \mathrm{C} / \mathrm{min}$ in a SPS equipment (Dr. Sinter 2050, Sumitomo Coal Mining Co., Tokyo, Japan) by allowing a pulsed direct current to pass through the pressure die, while an uniaxial pressure of $100 \mathrm{MPa}$ was continuously applied over the whole process. Sintering was carried out in vacuum. The holding time at the sintering temperature $\left(1200^{\circ} \mathrm{C}\right)$ was about $2-5 \mathrm{~min}$. Since the porosity in the dual membrane must be open to ensure water vapor elimination through interconnected paths of pores, a pore forming graphite powder with a platelet shape (Timrex, KS6 $\mathrm{d}_{50}=3 \mu \mathrm{m}$ ) was used. The total amount of pore forming agent was always in the range $30-50$ vol.\% and the volume ratio BCY15 / YDC15 in the solid phase was equal to 1, in order to ensure the percolation of the three phases present in the membrane. The sintered ceramics were annealed in air at $650^{\circ} \mathrm{C}$ for $10 \mathrm{~h}$ in order to remove graphite from the DM and excess of oxygen vacancies possibly produced during SPS.

The same multilayer structure was also prepared by HP in a dualaction die press HP50-7010G (Thermal Technology Inc.). A maximum sintering temperature of $1150^{\circ} \mathrm{C}$ was maintained for $60 \mathrm{~min}$ in argon atmosphere while a maximum pressure of $25 \mathrm{MPa}$ was continuously applied. Load was released during cooling. As for samples prepared by SPS, a heat-treatment at $650^{\circ} \mathrm{C}$ under oxidizing atmosphere was performed in order to burn all residual carbonaceous species arising from the graphite die pressure.

Alternatively, $1 \mathrm{~mm}$ thick samples with the same composition of layers were fabricated by tape casting the DM and the YDC15 electrolyte layers onto supporting BCY15 pellets prepared by $\mathrm{CP}$. Green tapes were deposited successively on the BCY15 substrate (sintered at $1450^{\circ} \mathrm{C}$ for 5 hours) with 20 min interval to allow for evaporation of most of the solvent. The assembly was then fully dried at room temperature for 2 hours before heating at $350^{\circ} \mathrm{C}$ for the decomposition of organic species and sintering at $1300^{\circ} \mathrm{C}$ for 5 hours. The slurry compositions are given in Table I: they are composed of the relevant powders, the solvent (Ethanol), the binder (PVB), the

\section{Table I. Slurries composition used for the elaboration of PoC} samples by tape casting.

Constituent Electrolyte SOFC Dual Membrane Electrolyte PCFC

\begin{tabular}{lccc}
\hline YDC & $6.0 \mathrm{~g}$ & $3.0 \mathrm{~g}$ & - \\
$\mathrm{BCY}$ & - & $3.0 \mathrm{~g}$ & $6.0 \mathrm{~g}$ \\
ZnO & - & - & $0.06 \mathrm{~g}$ \\
Ethanol & $4.8 \mathrm{~g}$ & $7.0 \mathrm{~g}$ & $5.2 \mathrm{~g}$ \\
PVB & $1.4 \mathrm{~g}$ & $2.2 \mathrm{~g}$ & $1.4 \mathrm{~g}$ \\
PEG & $0.30 \mathrm{~g}$ & $0.40 \mathrm{~g}$ & $0.40 \mathrm{~g}$ \\
Graphite & - & $1.2 \mathrm{~g}$ & -
\end{tabular}

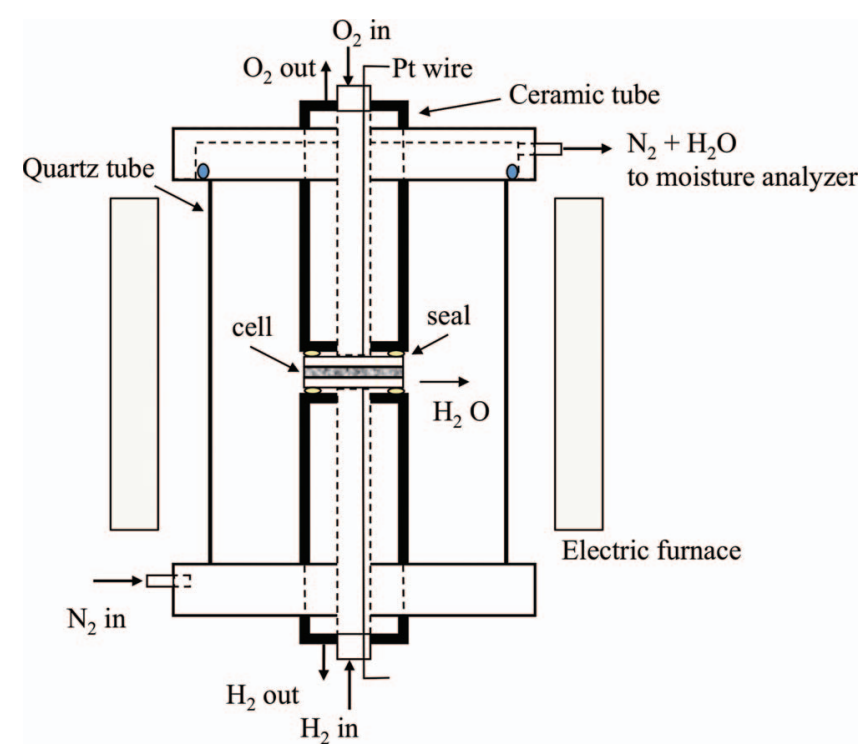

Figure 3. 3-chambers test rig for circular button cells. The sample is sealed on both surfaces (electrode compartments) and the DM is exposed to a different volume, flushed with a stream of inert gas.

plasticizer (PEG) and graphite as pore former for the DM. In order to better match the shrinkage of BCY15 and YDC15 during co-sintering, without significantly affecting the electrical properties, $1 \mathrm{wt} \% \mathrm{ZnO}$ was added to BCY $15 .^{22}$

Proof of concept electrochemical characterization.- PoC multilayers with $\mathrm{Pt}$ electrodes were tested in $\mathrm{O}_{2} / \mathrm{H}_{2}-\mathrm{H}_{2} \mathrm{O}(3 \mathrm{~mol} . \%)$ streams. The characterization of the cells was performed in a specially designed rig with a third chamber in order to separately detect water formation in the DM. The setup for PoC characterizations is represented in Figure 3. The rig housing for the cell electrode compartments is made of alumina tubes sealed on the flat surfaces of the samples, while that for the DM compartment is composed of a larger (diameter $8 \mathrm{~cm}$, length $80 \mathrm{~cm}$ ) quartz tube containing the whole rig. A tubular furnace (Carbolite, UK) with inner diameter $11 \mathrm{~cm}$ and $50 \mathrm{~cm}$ lenght was placed around the rig. A stream of $\mathrm{N}_{2}$ gas was fed to the DM chamber to remove the water vapor produced within the porous layer and to transfer it to a moisture analyzer (Manalytical, UK) for in-line measurement of humidity. The gas line between the hot DM chamber and the moisture analyzer was kept warm to avoid any condensation of water. Electrochemical characterization was carried out by means of a Potentiostat-EIS equipment (Metrohm Autolab, The Netherlands). Mass flow controllers (Bronkhorst, The Netherlands) were employed to select gas flow rates. The complete plasma sprayed metal-supported DM-Cell was tested in a 2-chambers set-up for 250 hours with $50 \%$ $\mathrm{H}_{2}-50 \% \mathrm{~N}_{2}$ at the anode and air at the cathode chamber respectively. $\mathrm{Pt}$ wires and meshes were used as current collectors.

\section{Results and Discussion}

Figure 4 shows the PoC cells prepared by SPS (a) and HP (b). The layered structure is clearly visible, with sharp and straight interfaces within the YDC15-DM-BCY15 sequence (top to bottom in 4a, right to left in $4 \mathrm{~b}$ ). For the proof of the DM-Cell concept the emphasis was essentially put on the robustness of the samples rather than on performances; particularly, no attempt to obtain thin electrolyte layers was made at this first stage of the new design development.

In general, SPS fabrication allowed a regular shape and tight adhesion of layers. Both oxygen and hydrogen electrolyte layers were dense and the DM pores were elongated along the radial direction, which should be most favorable for water vapor elimination ( $\mathrm{see}^{15}$ for microstructural details). The total thickness of the cells was in the 


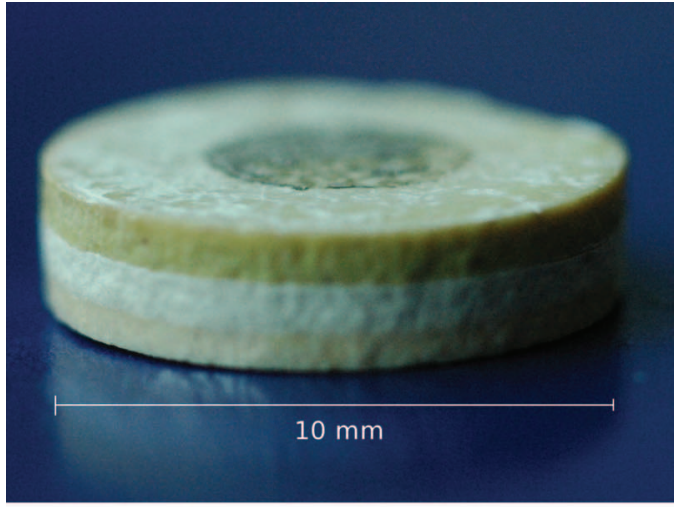

(a)

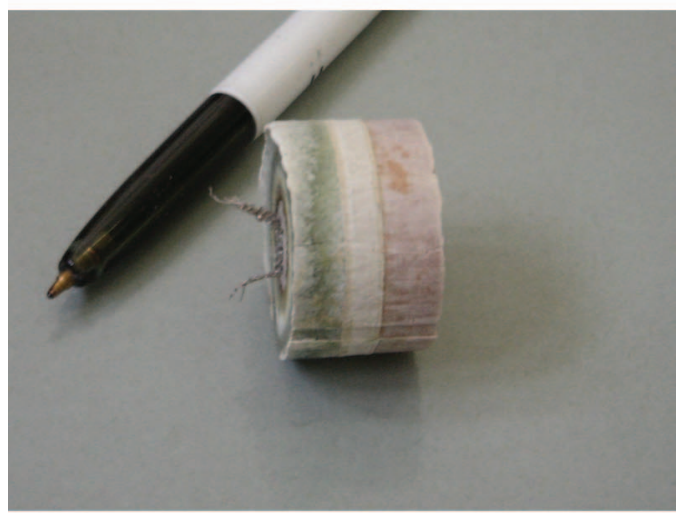

(b)

Figure 4. Photographs of PoC samples fabricated by SPS (a) and HP (b), after thermal treatment in air

range $2-3 \mathrm{~mm}$, i.e. about $0.7-1 \mathrm{~mm}$ for each layer. A similar result was obtained with HP: the sample was flat, compact and cracks-free, although the total thickness was much higher, about $16 \mathrm{~mm}$ (4 mm for the DM). The combination of TC and CP allowed for much thinner functional DM and YDC15 layers, as can be seen in the back scattered SEM image in Figure 5. The supporting BCY15 electrolyte $(0.6 \mathrm{~mm}$ thick) appears quite dense, though some residual closed porosity is visible. The DM (100 $\mu \mathrm{m}$ thick) is a homogenous mixture of the two phases (the darker phase is YDC15 and the lighter one is BCY15) while pores appear regularly distributed along the cell's diameter. Few larger agglomerates are also present. The YDC electrolyte is thinner $(30 \mu \mathrm{m})$ and completely dense. On top, the Pt cathode is also visible. It is worth noting that the compositions of the different layers,

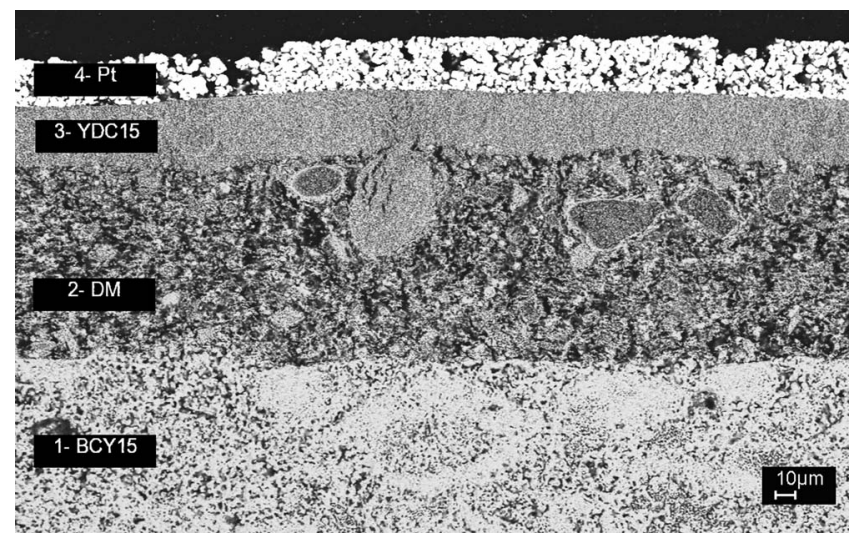

Figure 5. Cross section SEM image (back scattered electrons mode) of a PoC cell prepared by $\mathrm{CP}+\mathrm{TC}$.
Table II. Composition (at.\%) of the sample presented in Figure 5.

Nominal cationic ratios are reported between parentheses.

\begin{tabular}{cccccccc} 
Spectrum & $\mathrm{O}$ & $\mathrm{Y}$ & $\mathrm{Ba}$ & $\mathrm{Ce}$ & $\mathrm{Pt}$ & $\mathrm{Ba} / \mathrm{Ce}$ & $\mathrm{Y} / \mathrm{Ce}$ \\
\hline 1 & 67.98 & 2.29 & 15.57 & 14.16 & & $1.10(1.18)$ & $0.16(0.18)$ \\
2 & 69.82 & 3.27 & 7.69 & 19.21 & & $0.40(0.40)$ & $0.17(0.18)$ \\
3 & 71.62 & 3.71 & - & 24.68 & & - & $0.15(0.18)$ \\
4 & & & & & 100.00 & &
\end{tabular}

measured by Energy Dispersion X-ray Spectroscopy (EDXS, Oxford, UK) were very close to nominal values except for some $B$ a loss in the $\mathrm{BCY} 15$, as reported in Table II. In fact some evaporation of $\mathrm{BaO}$ can be expected at temperatures above $1400^{\circ} \mathrm{C}$, which however did not significantly affect the conductivity, as demonstrated on BCY15 pellets prepared by $\mathrm{CP}$ with the same powder and sintered at $1450^{\circ} \mathrm{C},{ }^{23}$ showing values (up to $15 \mathrm{mS} / \mathrm{cm}$ at $600^{\circ} \mathrm{C}$ ) close to the highest ones reported in literature. ${ }^{24}$

In a typical $\mathrm{PoC}$ experiment the cell was heated up at $900^{\circ} \mathrm{C}$ for 30 min under $\mathrm{N}_{2}$ in order to cure the ceramic sealing paste. Reacting gases were then fed during cooling down to testing temperatures (600$700^{\circ} \mathrm{C}$ ). PoC criteria were verified by measuring the cell potential under open circuit $(\mathrm{OCV})$ conditions, the polarization curve $(\mathrm{V}-\mathrm{i})$, the impedance and the humidity in the DM compartment.

i) $\mathrm{OCV}$

Figure 6 represents the cell voltage over a time interval of 23 hours measured on a sample prepared by combined $\mathrm{CP}$ and $\mathrm{TC}$. It was recovered after step polarizations to $0.2 \mathrm{~V}$ and was sensitive to temperature, changing from $0.96 \mathrm{~V}$ at $700^{\circ} \mathrm{C}$ to $1.05 \mathrm{~V}$ at $600^{\circ} \mathrm{C}$. This behavior is common to all kinds of fuel cells and the OCV values are close to the theoretical ones for $\mathrm{H}_{2}-\mathrm{O}_{2}$ cells. Similar stable OCV behavior was recorded for the PoC cells prepared by SPS or HP.

ii) Polarization curve

Figure 7a reports the polarization curve measured on a sample fabricated by combined $\mathrm{CP}$ and TC under $\mathrm{H}_{2}-\mathrm{H}_{2} \mathrm{O} /$ air feeding. The response was reproducible and sensitive to temperature, as it is expected in a standard high temperature fuel cell. The specific power output was relatively low (about $5 \mathrm{~mW} / \mathrm{cm}^{2}$ at $600^{\circ} \mathrm{C}$ ), which can be attributed to the un-optimized thickness of the active layers (electrolytes and DM). Similar polarization behavior was recorded for the other PoC cells prepared by SPS or HP (Fig. 7b). At low current densities and $600^{\circ} \mathrm{C}$ the cell behavior is strongly governed by activation mechanisms. At $700^{\circ} \mathrm{C}$ a linear trend of the $\mathrm{I} / \mathrm{V}$ curve is displayed suggesting that ohmic resistance of the ionic conductors is controlling the process even at low current densities.

iii) Humidity in the DM compartment

The formation of water vapor in the DM was directly detected by means of a moisture analyzer connected in line to the third chamber of the test rig. After equilibration at working temperature with

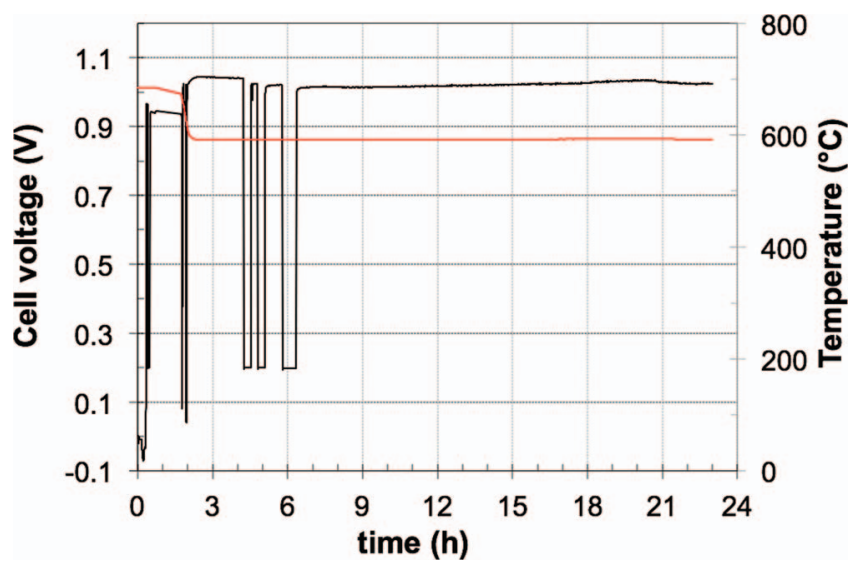

Figure 6. OCV and temperature evolution in a PoC experiment. 

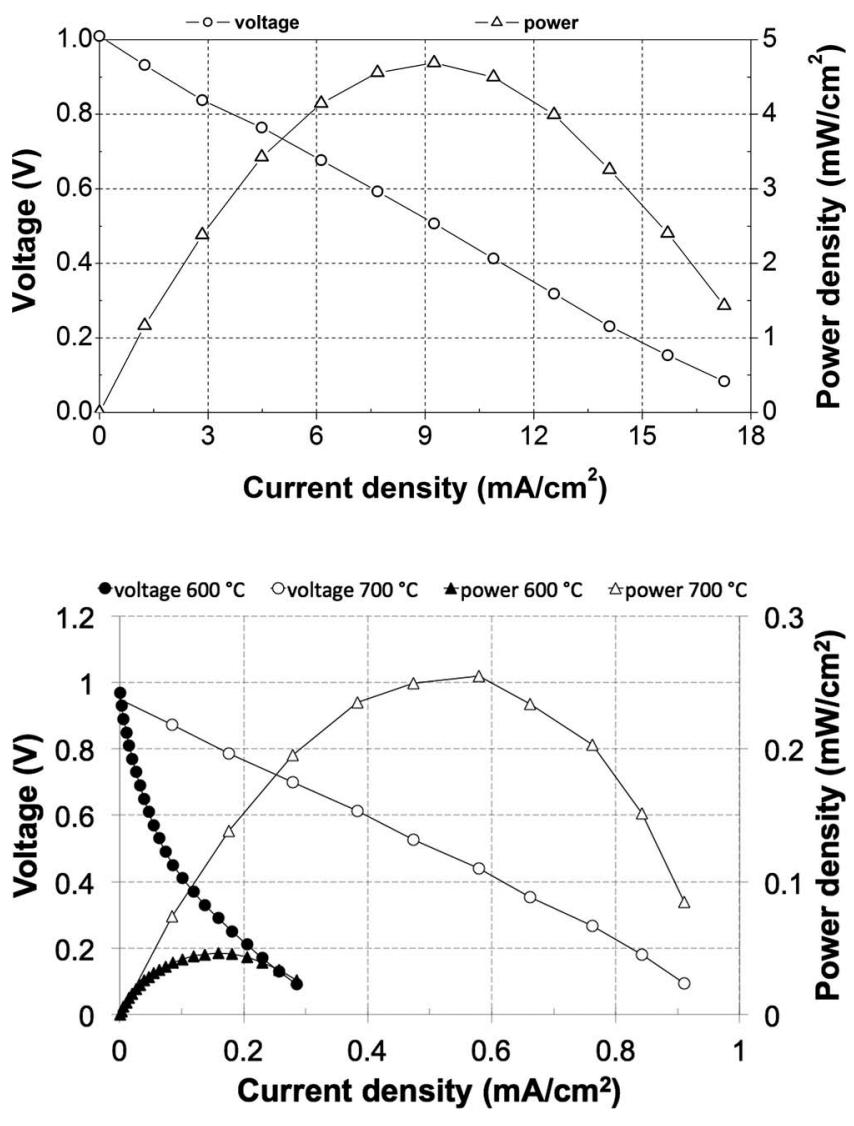

Figure 7. Polarization curves of: a) PoC cell fabricated by $\mathrm{CP}+\mathrm{TC}\left(600^{\circ} \mathrm{C}\right)$; b) PoC cell fabricated by $\mathrm{HP}\left(600\right.$ and $\left.700^{\circ} \mathrm{C}\right)$.

$\mathrm{H}_{2}-\mathrm{O}_{2}$ feeding at electrodes and $\mathrm{N}_{2}$ in the DM chamber $\left(\mathrm{N}_{2}\right.$ flow rate $100-150 \mathrm{Nml} / \mathrm{min}$ ), step polarization was applied. Electric current flowing in the external circuit and humidity concentration in the $\mathrm{N}_{2}$ stream were recorded. One example, obtained on a sample prepared by SPS, is reported in Figure 8 . The result clearly shows that water is produced in the DM compartment during polarization.

iv) Impedance fingerprint for the appearance of water.

Characteristic low-frequency inductive loops (in the range $10^{0}-10^{-2}$ ) $\mathrm{Hz}$ were observed in EIS spectra for all PoC samples (Fig. 9). The negative differential resistance associated to those loops corresponds to the formation of a new phase and has already been identified in other systems, like batteries. ${ }^{25-28}$ In our case these characteristic features are associated to the formation of water in the DM. A detailed discussion of this fingerprint for water production in the DM-Cell observed in EIS spectra is given elsewhere. ${ }^{18}$

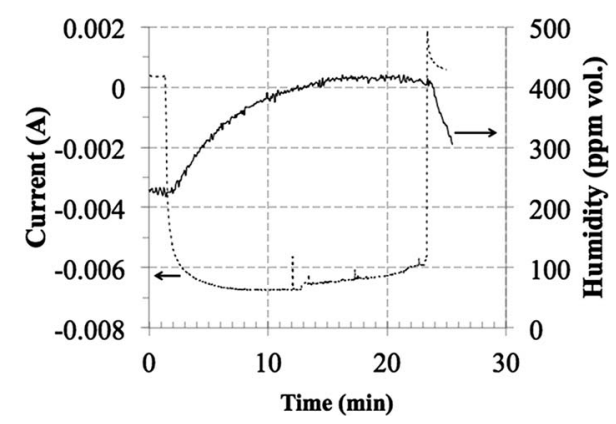

Figure 8. Correlation between electric current and humidity in the DM compartment of a PoC cell fabricated by SPS.

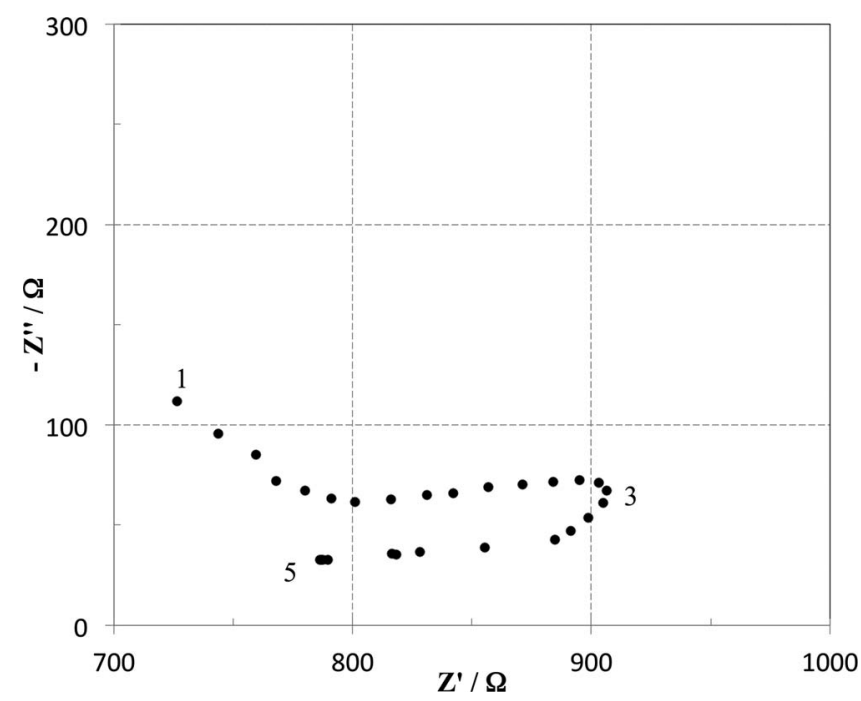

Figure 9. Impedance plot of a PoC sample prepared by SPS. $\mathrm{T}=600^{\circ} \mathrm{C}$, a.c. signal amplitude $=5 \mathrm{~mA}$.

The overall results demonstrate that in spite of the poor performances of PoC cells, basically due to the non-optimized geometry, all of the criteria defined for proving the DM-Cell concept were fulfilled: (i) a very stable $\mathrm{OCV}$ close to $1.0 \mathrm{~V}$ typical for the electrochemical potential of water formation from hydrogen and oxygen was recorded (for long duration), also indicating that the rig and samples were perfectly gastight; (ii) a stable and reproducible polarization curve of a typical high temperature fuel cell was recorded; (iii) a clear correlation between the current flowing through the cell and the humidity in the DM was found; (iv) specific features in the EIS were observed due to formation and growth of a new phase, identified as being water vapor.

Performance improvement of the Dual-Cell design. - The obtained results on thick $\mathrm{PoC}$ samples produced by different techniques confirmed the concept for the operation of the dual membrane design. For improving the cell performance, a technological approach based on the plasma spraying (PS) technique was developed for production of a thinner cell. This technique is a time and cost-effective alternative to the conventional shaping and sintering processes. ${ }^{29}$ The five functional layers of the DM-Cell were developed separately by applying thermal spraying technologies. A $1 \mathrm{~mm}$ thick and porous metallic substrate (48 $\mathrm{mm}$ in diameter) was used as support for the deposition of the BCY15 / NiO cermet anode precursor, which was then reduced at high temperature in order to get metallic Ni. All other layers were sprayed successively in the appropriate order, up to the YDC15 electrolyte. The cathode layer made of LSCF48 was brushed and annealed in situ before testing.

A $48 \mathrm{~mm}$ diameter plasma sprayed DM-cell with a total functional layer thickness of $180 \mu \mathrm{m}$ was successfully fabricated. Figure 10 presents a cross sectional view of the PS DM-cell deposited on a $1000 \mu \mathrm{m}$ thick porous metallic substrate after 250 hours of operation at $600^{\circ} \mathrm{C}$ and $700^{\circ} \mathrm{C}$. After reduction of $\mathrm{NiO}$ at high temperature, the resulting $35 \mu \mathrm{m}$ thick BCY15-Ni anode layer exhibited sufficient porosity for an easy permeation of hydrogen. Above, a relatively dense $35 \mu \mathrm{m}$ thick BCY 15 electrolyte displaying substantially globular and closed porosity, led to a gas leakage rate which was found to be acceptable. The following $45 \mu \mathrm{m}$ thick porous composite DM exhibited a very good adherence along the radial axis. The second electrolyte (YDC15) was $50 \mu \mathrm{m}$ thick and presented a relatively high level of micro cracks. Finally the LSCF cathode was $10-15 \mu \mathrm{m}$ thick.

The cell was fully tested in the temperature range $600-800^{\circ} \mathrm{C}$, with $\mathrm{H}_{2}-\mathrm{H}_{2} \mathrm{O}$ (3 at.\%) / air feeding. Polarization curves at three different temperatures are reported in Figure 11. OCV was $1.05 \mathrm{~V}$ at $600^{\circ} \mathrm{C}$, stable over the whole life cycle of about 200 hours. Performances were rather encouraging $\left(\mathrm{P}_{\max }\right.$ up to $132 \mathrm{~mW} / \mathrm{cm}^{2}$ at $\left.800^{\circ} \mathrm{C}\right)$ 


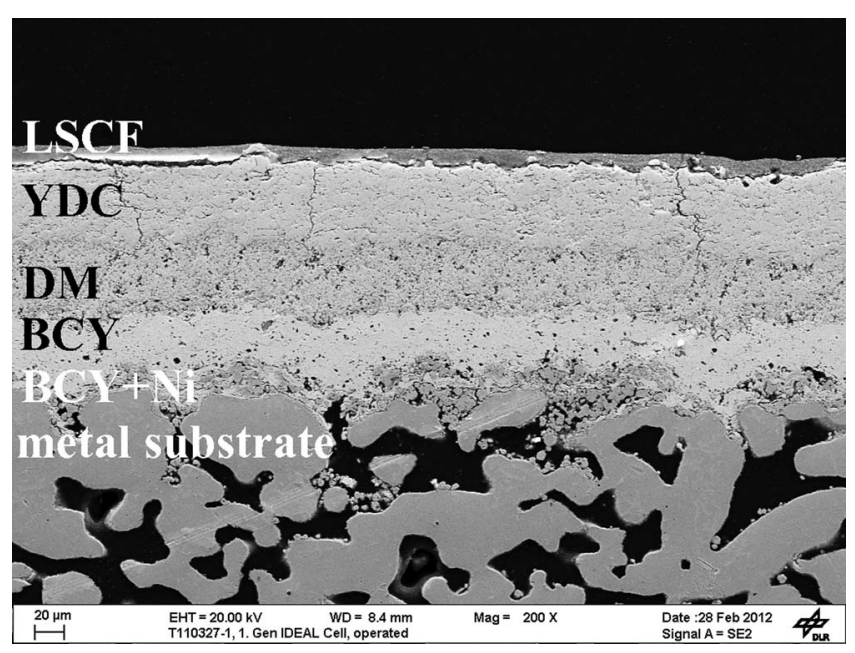

Figure 10. SEM image of the complete DM-Cell fabricated by PS.

although limited by both kinetic and ohmic losses, especially at lower temperatures.

The successful fabrication of a complete DM-Cell by PS demonstrated the feasibility of this innovative architecture by means of industrial processes.

It should also be noted that, even if the DM-Cell design with its five layers appears a priori more complicated to fabricate than standard SOFCs, the difference may not be that consistent since the latter usually requires additional layers as diffusion barriers at electrodeselectrolyte and electrodes-interconnects interfaces, which is not the case of the DM design.

Significant improvements can be expected by careful composition and microstructure adjustment and by fine control of layers thickness. In addition, the detailed modeling taking into account mechanisms and kinetics of water recombination, the specific ionic conductivities of electrolytes, and the transport and exhaust of the produced water ${ }^{15}$ is expected to give essential guidelines (volume fraction of each solid phase in the DM, size and morphology of pores, thickness of components, grain size... ) for the fabrication and design of an optimized dual membrane with reduced ohmic losses and overpotentials.

Another promising direction toward optimization of the DM Cell performance is the development of the so called "monolithic concept" $" 30,31$ in which YDC in both the electrolyte layer and the DM is replaced with BCY which was found to have good mixed conductivity at operating temperatures. ${ }^{23,32}$ The first experimental results are very promising - a better performance (maximum power density of 75 $\mathrm{mW} / \mathrm{cm}^{2}$ at $700^{\circ} \mathrm{C}$ ) was registered for $1 \mathrm{~mm}$ thick monolithic design with Pt electrodes against $71 \mathrm{~mW} / \mathrm{cm}^{2}$ for classical proton conducting

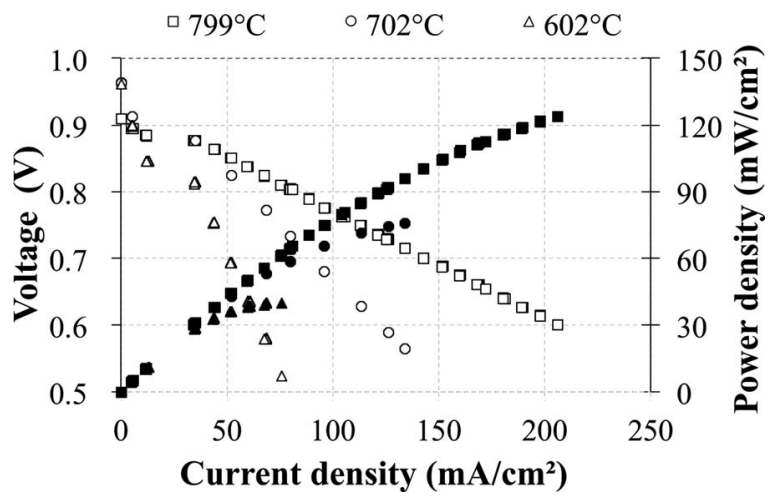

Figure 11. Performance of the plasma sprayed DM-Cell at 600, 700, and $800^{\circ} \mathrm{C}$. cell with thickness $600 \mu \mathrm{m}$, produced by the same technology with the same materials. ${ }^{10}$

\section{Conclusions}

An innovative architecture for high-temperature fuel cells, the DM-Cell, has been fabricated and tested. The electrochemical studies performed on 3-layer samples (dense BCY15 protonic electrolyte/ porous BCY15-YDC15 dual membrane/ dense YDC15 anionic electrolyte with thin porous platinum electrodes) confirm that the system behaves electrochemically as a fuel cell with water production in the DM compartment. A complete DM-Cell was also fabricated by thermal spraying, which exhibited a maximum power density of $132 \mathrm{~mW} / \mathrm{cm}^{2}$ at $800^{\circ} \mathrm{C}$.

\section{Acknowledgments}

Authors are grateful to Dr. Z. Zhe, Stockholm University, for the preparation of samples by SPS and to Marion Technologies S.A., Verniolle-France, for supplying ceramic powders. They are also most grateful to Professors Paolo Spinelli and Nikolas Bonanos for enjoyable and fruitful discussion about the concept. The research leading to these results has received funding from the European Community's Seventh Framework Program (FP7/2007-2013) under grant agreement No 213389.

\section{References}

1. A. J. Jacobson, Chemistry of Materials, 22, 660 (2010).

2. J. Dailly, S. Fourcade, A. Largeteau, F. Mauvy, J.-C. Grenier, and M. Marrony, Electrochimica Acta, 55, 5847 (2010).

3. H. B. Yahia, F. Mauvy, and J.-C. Grenier, Journal of Solid State Chemistry, 183, 527 (2010).

4. H. Ding, Y. Xie, and X. Xue, Journal of Power Sources, 196, 2602 (2011)

5. N. P. Brandon, S. Skinner, and B. C. H. Steele, Annu. Rev. Mater. Res., 33, 183 (2003)

6. S. Singhal, Solid State Ionics, 152-153, 405 (2002).

7. M. Henke, J. Kallo, K. A. Friedrich, and W. G. Bessler, Fuel Cells, 11, 581 (2011).

8. P. Piccardo, P. Gannon, S. Chevalier, M. Viviani, A. Barbucci, G. Caboche, R. Amendola, and S. Fontana, Surface and Coatings Technology, 202, 1221 (2007).

9. A. Thorel, Cellule de pile a combustible haute température à conduction mixte anionique et protonique. French Patent $\mathrm{N}^{\circ} 0550696000$ (2005).

10. Innovative Dual mEmbrAne fuel Cell: IDEAL Cell. www.ideal-cell.eu (2008).

11. A. S. Thorel, A. Chesnaud, M. Viviani, A. Barbucci, S. Presto, P. Piccardo, Z. Ilhan, D. Vladikovaf, and Z. Stoynov, in S. C. Singhal and H. Yokokawa (Eds.), Solid Oxide Fuel Cells 11 (SOFCXI), The Electrochemical Society Proceedings Series, ECS Transactions, Vol. 25 (2), Pennington, NJ (2009) 753.

12. N. Bonanos, in "High temperature behaviour of fast ion and mixed conductors", Proc 14th Risф Intl. Symposium on Mat. Sci., Risф Denmark, (1993) 19.

13. T. Shimura, G. Egusa, H. Iwahara, K. Katahira, and K. Yamamoto, Solid State Ionics, 97, 477 (1997).

14. M. Henke, C. Willich, C. Westner, F. Leucht, R. Leibinger, J. Kallo, and K. A. Friedrich, Electrochimica Acta, 66, 158 (2012).

15. T. Ou, C. Nicolella, F. Delloro, W. G. Bessler, and A. S. Thorel, J. Electrochem. Soc. submitted and accepted as a Part II companion paper (this issue).

16. J. W. Fergus, Materials Science and Engineering: A, 397, 271 (2005)

17. J. Larminie and A. Dicks, Fuel Cell Systems Explained, p. 37, John Wiley \& Sons Ltd., Chichester U.K. (2003).

18. D. Vladikova, Z. Stoynov, G. Raikova, A. S. Thorel, A. Chesnaud, J. Abreu, M. Viviani, A. Barbucci, S. Presto, and M. P. Carpanese, Electrochimica Acta, 56, 7955 (2011).

19. G. Caboche, J. Hochepied, P. Piccardo, K. Przybylski, R. Ruckdaschel, M.-R. Ardigo, E. Fatome, S. Chevalier, A. Perron, L. Combemale, M. Palard, J. Prażuch, and T. Brylewski, ECS Trans., 25(2), 763 (2009).

20. R. V. Wandekar, B. N. Wani, and S. R. Bharadwaj, Solid State Sciences, 11, 240 (2009).

21. G. Chiodelli, L. Malavasi, C. Tealdi, S. Barison, M. Battagliarin, L. Doubova, M. Fabrizio, C. Mortalo`, and R. Gerbasi, Journal of Alloys and Compounds, 470, 477 (2009).

22. M. Amsif, D. Marrero-López, J. C. Ruiz-Morales, S. N. Savvin, and P. Núñez, Journal of Power Sources, 196, 9154 (2011).

23. M. Viviani, S. Presto, A. Barbucci, M. P. Carpanese, R. Amendola, A. S. Thorel, A. Chesnaud, J. Abreu, R. Costa, Z. Ilhan, S.-A. Ansar, D. E. Vladikova, and Z. B. Stoynov, MRS Proceedings, 1330, mrss11-1330-j05-04 (2011).

24. N. Bonanos, Solid State Ionics, 145, 265 (2001).

25. C. Gabrielli, in "Identification of Electrochemical Processes by Frequency Response Analysis" Technical Report No 004, Solartron, Farnborough, Hampshire, England 1980. 
26. Z. Stoynov, B. Savova-Stoynov, and T. Kossev, J. Power Sources, 30, 285 (1990).

27. A. Chahremaninezhad, E. Asselin, and D. G. Dixon, Electrochim. Acta, 55, 5041 (2010).

28. A. Barbucci, G. Bruzzone, M. Delucchi, M. Panizza, and G. Cerisola, Intermetallics, 8, 305 (2000).

29. A. Ansar, Z. Ilhan, G. Schiller, O. Patz, and J. B. Gregoire, in International Thermal Spray Conference (ITSC) 2008 Proceedings, E. Lugschneider, Editor, p. 190, DVSVerlag GmbH, Düsseldorf (2008).
30. A. Thorel, D. Vladikova, Z. Stoynov, A. Chesnaud, M. Viviani, and S. Presto "Fuel cell with monolithic electrolytes membrane assembly", US patent 20120156573/21 (2012).

31. Z. Stoynov, D. Vladikova, A. Thorel, A. Chesnaud, M. Viviani, and A. Barbucci "Architecture of (High Temperature) Fuel Cell with Bi-Layered Mixed Conducting Electrolyte", Patent filing number 1159969 (2011).

32. M. Krapchanska, D. Vladikova, Z. Stoynov, A. Chesnaud, J. Abreu, A. Thorel, and G. Raikova, in: D. Vladikova and Z. Stoynov (eds), Proc. Internat. Workshop Advances and Innovations in SOFCs 2 pp. 72-77 (2011). 